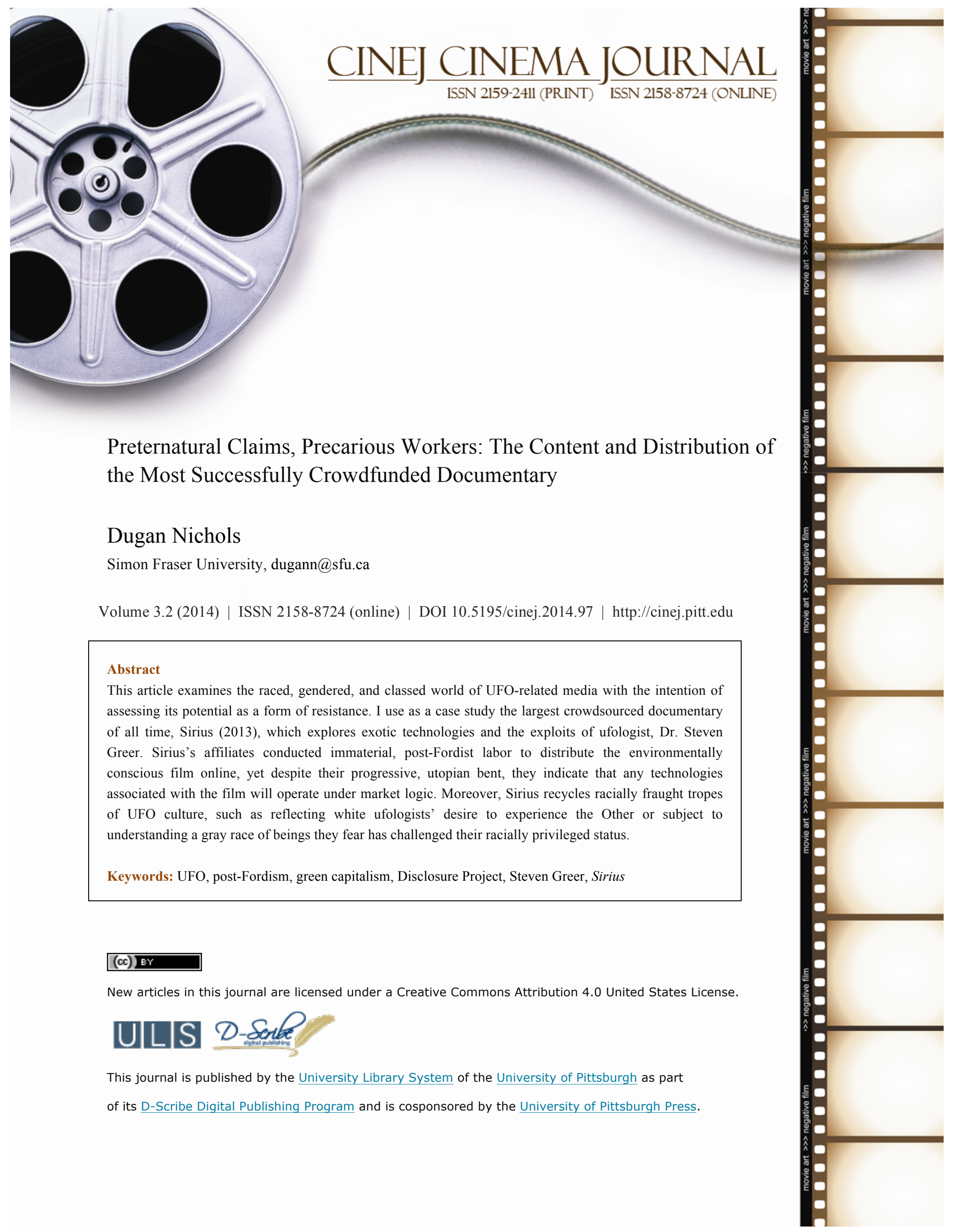




\section{Preternatural Claims, Precarious Workers: The Content and Distribution of the Most Successfully Crowdfunded Documentary}

\section{Dugan Nichols}

This article is concerned with the raced, gendered, and classed ideologies endemic to the culture surrounding UFOs (and by extension the offshoots of conspiracy theories and claims surrounding "free energy"). While these ideologies and expressions are longstanding in the US, I primarily refer to their recent incarnations in the current capitalist epoch, dubbed "post-Fordist" by the French Regulation School. ${ }^{1}$ Since UFO enthusiasts routinely promote their beliefs through discursive products distributed under the dictates of this new economy, I examine both the identity politics of UFO culture as expressed in its media and the slick forms of entrepreneurialism that sustain the culture. As I will explain, this entrepreneurial ethos is bent on spreading truth and creating a more sustainable world on the one hand while condemning file sharing and championing "green capitalism" on the other. As case studies, I use Dr. Steven Greer (founder of the UFO organization known as the Disclosure Project) and the 2013 film he sanctioned, Sirius, which the producers have billed as "the largest crowdfunded documentary in history." "Sirius is not only a rich text to analyze but representative of the broader UFO culture as well. Given this, a critical reading of the film shows how elements of an entire fringe culture bear on questions of race, gender, and class. But before offering an extended analysis of what UFO culture entails, I will introduce its history.

Though speculation about mysterious sightings in the sky has existed for centuries, the culture only reached its modern form in 1947.- when the press coined the term "flying saucer" and broke news of the famed Roswell "crash" in New Mexico. ${ }^{3}$ The belief in UFOs would go on to provide a big tent, admitting various UFO-related cults ${ }^{4}$ as well as methods of 
empirical analysis emulative of the sciences. ${ }^{5}$ During what Jodi Dean refers to as the "alien age," the culture has led to innumerable, popularized manifestations in the mainstream experience, resulting in media saturation and the pervasive common knowledge of extraterrestrial narratives. $^{6}$

While this sphere of belief appears at first to possess some faintly counterhegemonic properties (e.g., a suspicion of government secrecy), ufological acolytes nonetheless express assumptions that invoke racial and class privilege. Furthermore, if these acolytes do voice disapproval of, say, the capitalist system, they do so with truncated understandings of what makes it exploitative. I will illustrate these fractious and contradictory views of capital and the state in subsequent sections.

\section{Defining the Disclosure Project, Sirius, and Forms of Capital}

The Disclosure Project is one of the more publicized organizations in the ufological community. Launched in 1993 by a former ER doctor, Steven Greer, the outfit exists to press US and foreign officials to reveal their knowledge of UFO-related phenomena. The Project was successful in this despite its few resources, securing 120 hours of videotaped testimony within its first seven years. ${ }^{7}$ During this time, Greer's mission had also thrust him into the highest of Washington echelons, gaining access to the Clinton administration and the head of the CIA. But he faced the greater challenge of commanding Congress' attention with the hope of establishing hearings on his testimonial bombshells. It seemed Greer could push only so far before succumbing to what he calls the "ever-present ridicule that attends [the UFO] subject." 8

But it is not merely the concept of extraterrestrials that defines the Disclosure Project's agenda. It has moreover alleged the existence of "Earth-saving technologies" that 
remain classified by a government under the thumb of Big Oil. ${ }^{9}$ This assertion would later take center stage in Sirius.

Director Amardeep Kaleka, producer J.D. Seraphine, and the production studio Neverending Light collaborated with Greer to create the documentary. The title refers to the night sky's brightest star, which is used here metaphorically as a beacon to bring all factions of the UFO and conspiracy communities together. ${ }^{10}$ Budgeted at $\$ 250,000$, it premiered in Los Angeles and New York City on Earth Day 2013. It features the Hollywood actor Thomas Jane as narrator and music by renowned artist, Moby. In addition to its impressive visuals, the film espouses all things alien, from historical ET visitations (resulting in ancient nuclear explosions in what is now Pakistan) to CE-5 (or Close Encounters of the Fifth Kind) in which Greer purports to contact alien ships through meditation.

Less paranormal claims appear as well, such as libertarian oriented US Federal Reserve conspiracies and clampdowns on amateur scientific innovations. Regarding the latter, Greer states in a trailer for the film: "Here we sit, in 2012, with the world still burning oil and gas and coal, when we have and all the information we need to have had a completely new civilization."11 The quote is important to unpack for two reasons: First to indicate how the Project poses as a synecdoche for the rest of ufology, and second to illustrate the Project's troubled flirtation with capitalist solutions to contemporary environmental crises.

Greer's quote bespeaks a long established relationship between a strain of paranoid environmentalism and UFO culture, as aliens allegedly screen images for their abductees of the earth decimated by atomic blasts or pollution. ${ }^{12}$ This happened notably to ufology icon and best-selling author, Whitley Strieber, who uttered under hypnosis that his captors displayed "pictures of the world just blowing up" with "dark red fire in the middle of it." "Secondly, 
Greer's ire in Sirius toward the "Four Horsemen" banking families who own the world's four largest oil firms seems to express a radical or even anti-capitalist position. In fact, a critic on the right even charged the hype around the documentary as such. ${ }^{14}$ In this sense, Sirius and the formation it speaks for could pose as a potential albeit fringe source of progressive resistance.

Yet perceiving the group in such a manner would mean ignoring the history of populist, rightwing strains boasting interpretations of the world that prefigure Greer's and his disciples' own views. An example in this lesson on ideology comes by way of Stuart Hall et al. in the Gramsci inflected Policing the Crisis, where they discuss Britain's rightwing National Front, which, in regard to questions over race, poverty, and crime in the 1970s, endorsed an antiimmigrant political platform also based on antipathy towards big business and banks. The authors state this was "calculated to nourish unorganized white working-class resentment during a period of economic recession." ${ }^{\prime 15}$ One may hear echoes here of the more recent Tea Party media darlings who came to prominence during Barack Obama's first term. The point, though, is to highlight that powerful institutions (e.g., the state) can nonetheless sway these same "common-sense" ideologies of the working class to gel with the dominant ideology, which, in Hall et al.'s case, dealt with advocating severe retribution over Black "muggings" of whites. ${ }^{16}$ In light of this, the problematic issues with Greer's position quickly become apparent. Moreover, while Sirius presents a case against destructive natural resource extraction, the film's affiliates conversely herald the quintessence of green capitalist solutions while simultaneously abiding by more flexible forms of profit accumulation (i.e., exigencies under the post-Fordist economy). But to clarify before moving further, I offer a distinction between these two concepts. Post-Fordism is a period emerging after the 1970s, posing here as the larger political economic context in which these issues unfold. It is accompanied by the near 
synonyms: post-industrialism, late capitalism, neoliberalism, and the "new capitalism."17 Regardless of the definition, the evolutionary period carries demands market actors must respect if they expect to succeed. For one small example, I look to the Project's website, siriusdisclosure.com, which makes DVDs of the film available for sale. Yet the "Order Video on Demand" option appears above the "Buy the DVD" option. The placement is telling in that the Project intends the film be distributed immaterially, which has the side consequence of reaffirming Greer's aversion to forms of antiquated capital—a sentiment other contemporary entrepreneurs no doubt share. As Enda Brophy writes, post-Fordist industries rely on a precarious workforce to provide the immaterial labor behind "Web design, call-centre work, and computer programming," suggesting Greer's efforts complement the new paradigm. ${ }^{18}$

By contrast, green capitalism is a product of the "neoliberal turn,"," and it represents the "responses to environmental change... that [rely] on harnessing capital investment, individual choice, and entrepreneurial innovations to the green cause. ${ }^{.20}$ In this reading, Greer is seen as the "elite bourgeois subject" investing in market solutions aimed at addressing the environmental crisis, much like tycoon Richard Branson's 2006 commitment to combatting climate change to the tune of 1.6 billion pounds. ${ }^{21}$ Prudham's work on this contradictory form of capital will factor in when I discuss solutions proposed by the Project and its affiliates. First, though, I offer a more explanatory characterization of the UFO culture that would beget a media artifact such as Sirius.

UFO Culture and Its Media

CINEJ Cinema Journal: Preternatural Claims, Precarious Workers

Volume 3.2 (2014) ｜ＩSSN 2158-8724 (online) ｜ DOI 10.5195/cinej.2014.97 | http://cinej.pitt.edu 
Cultural theorist John Fiske argued that in a late-capitalist society, ways of understanding the world are poststructural in nature, meaning that diverse actors from different raced and classed backgrounds can converge to articulate and defend a position or take a side only to disappear after having secured alliances. The sides that materialize and clash over any given issue are unequal in terms of resources, finances, and backings; institutional factions project "imperializing" knowledge, whereas individuals project a "localizing" one. ${ }^{22}$ They proceed to engage in a Gramscian winning of consent_-described elsewhere as a "state of play in the class struggle which has... to be continually worked on and reconstructed in order to be maintained."23 Fiske associates UFO belief with localizing knowledge (along with Elvis sightings, etc.), so he provides an apt framework in which to view the culture in general. ${ }^{24}$ Due to ufology's inherent subjectification as loony and on the defensive from established science, it has to bill itself as scientific. As Fiske says of numerology and astrology, they must "dress themselves as 'sciences' to gain some of the status from which they are officially excluded." 25 In light of these setbacks, ufologists defend their legitimacy by employing several "rhetorical strategies," such as "emulating mainstream science." 26 Ufologists likewise contribute to academic journals such as The Flying Saucer Review - run by medical doctors, astronomers, and physicists. $^{27}$ The culture's groups such as MUFON, NICAP, and APRO also steep "themselves in science and law."28

Considering social movement theory, however, UFO culture can also be helpfully understood in a less poststructuralist manner. I refer here to Dorceta E. Taylor's lucid article on the advent of the environmental justice movement, which hinges on issues germane to people of color. In this regard, she can provide a useful framework in order to place Greer and the followers who contributed to the making of Sirius - a discursive media form that of course 
makes environmental claims of its own. In describing the mainstream (i.e., white and middleclass) environmental movement, Taylor writes that members can count on politicians to be allies and, given this, have the tactic of lobbying at their disposal. ${ }^{29}$ Despite Greer's personal class background, his movement is unable to necessarily influence Congress, leaving him only with "direct-action" options, which Taylor says entail protests and rallies. ${ }^{30}$ Sirius begins, incidentally, with Greer delivering a well-attended lecture. Moreover, Taylor writes that an effective movement demonstrates to potential converts how they have a personal experience with the problem at hand. ${ }^{31}$ In an example of this, Greer alludes in an interview segment to the major shift that will occur in driving one's truck after his projected energy revolution. ${ }^{32}$ Lastly, Taylor notes that activists "redefine existing roles within established organizations and use these as templates for creating new identities," which was the case for the 1960s civil rights movement as it blended its cause with churches - a "salient" presence in the African-American community. ${ }^{33}$ One can potentially view Greer as doing something similar in Sirius, linking broader UFO phenomena to a focused campaign of usurping the oil and gas industries.

In any event, the most active UFO enthusiasts are primarily white males who often boast advanced degrees and/or training (and Greer is no exception). While this is made clear throughout the culture, one may look no further than the composition of the Mutual UFO Network (MUFON), which claims nearly 500 members with PhDs-a sixth of the group's total. ${ }^{34}$ The trend bespeaks social privilege, ready access to wealth, and a bias within the culture. The white men composing UFO culture may indeed harbor an underlying desire to understand what must be a more superior race (i.e., grey alien beings), which could stem from the creeping anxieties they feel regarding their position atop the social hierarchy. Subconsciously motivating UFO enthusiasts could very well be the attempt to control a force 
that exceeds the power of their own identity. I would argue that two books in particular evince this struggle, which will segue into a wider discussion of the racialization of UFO media.

Whitley Strieber's Communion (1987) is purportedly nonfiction, though it details the man's fractured life as an alien abductee. The book is rife with high literary epigraphs and the eloquent prose of a professional author, which Strieber was and is. In this reading, his experience illustrates the unconscious attempt by white males to protect their position atop the social hierarchy as a black-eyed and grey (or in his case, more tan) race exceeds them technologically. In a telling passage, he reports that he almost titled the book Body Terror to aptly capture the "extreme physical sensation of fear" he felt when ETs invaded his bedroom. ${ }^{35}$ Noted feminist, bell hooks (who also happened to pen an unrelated book titled Communion), writes in Killing Rage that "black folks associated whiteness with the terrible... [and] terrifying" when whites would enter their neighborhoods in the Jim Crow south. ${ }^{36}$ Since the two figures, one a white male, the other a Black woman, both employ this sort of language to describe the frightening prospect of encroachment by a different race, it is reasonable to interpret Strieber's bedside visitations as a manifestation of the fear of watching one's racial privilege slip away. One may especially consider Strieber's account when hooks goes on to ask, "Did they not understand at all how strange their whiteness appeared in our living rooms? ${ }^{, 37}$ Read thusly, triumphing over Strieber's identity is the othered alien, which Elspeth Kydd has elsewhere described as "an extreme of whiteness, without orifices or genitalia" - and in that sense, an eve more idealized being. ${ }^{38}$

Race in UFO media is the subject of a number of studies, which is important to invoke in order to show how the existing attitudes in ufology prefigured Sirius-which then reflects back some of the same themes that I delineate here. Perhaps the most seminal of these is 
articulated in Heather J. Hick's study on the film, Men in Black (1997), which she says illustrates authors' and filmmakers' tendencies of employing extraterrestrial imagery to "articulate the dominant white culture's fear and antagonism toward people of other races."39 Clearly, this was the case in Communion, and it carries over as well into televised portrayals in the form of The X-Files (1993-2002) — where the white leads can "speak for the commonality of humanity" in the face of "nonhuman Others." History's Ancient Aliens propounds that visiting extraterrestrials constructed monuments the world over, which suggests often non-white, historical peoples lacked the architectural adeptness to build the megaliths themselves. ${ }^{41}$ And going back to the "nonfiction" bestseller medium, The Interrupted Journey (1966) documents the abduction of an interracial couple who had already experienced "heavy pressure" over their marriage. ${ }^{42}$ David Drysdale writes that abduction stories like these could indicate the anticipation of a "postracial future" given the ETs collapsing of "a multitude of racial and cultural signifiers." 43

\section{Sirius, Race, and Resistance}

Thinking back to Strieber, the notion that extraterrestrials have the capacity to dominate the oppressive white race surfaces elsewhere too, namely in the belief structure of the Nation of Islam, in Black Afrofuturist music, and in Australian Aboriginal culture. Yet in these instances, the cosmos and its interplanetary beings are deliberately and rhetorically called upon as a strategy of Black empowerment. Following this brief discussion, I will show how Sirius adheres to similar conventions but from an inverse angle.

The musicians associated with the Afrofuturist genre today involve Cee-Lo and Kool

Keith, but preceding them were 1970s-era George Clinton and 1950s-era Sun-Ra-who 
asserted that Jupiter hosted his birth. J. Griffith Rollefson writes that this funk and hip-hop music collectively serves to undermine empiricist, Western sentiments that claim as their "standard bearer... white supremacy." ${ }^{44}$ Relatedly, Nation of Islam VIPs, Louis Farrakhan and Elijah Muhammad, also appropriated cosmic themes to challenge and marginalize the white establishment. Central to these is the Mother Wheel, a UFO-like vehicle that allegedly plucked Farrakhan from a Mexican ruin in 1985. In a subsequent press conference, he affirmed the Wheel as a protector of the Black population, adding that whites “can't touch it... can't knock it down... [and that] there is no rocket that they have that can reach it."45 Likewise, Muhammad taught that Black beings populate other planets, expressing, "You have people on Mars! Think about how great you are. Ask the white man if he has any out there. We have life on other planets, but he don't." ${ }^{, 46}$ The same sentiment is echoed in remote Australia, where Aboriginals can rhetorically trump whites (who have only been to the moon) by praising the ingenuity of ETs who can "travel across the universe.",47

In these cases, the tactic of avowing great cosmological feats —of claiming spaces and machines beyond the reach of white colonization - functions as a way to flex Black superiority. The struggle in Sirius, however, represents a direct racial inverse, since whiteness fails to factor as a cause of social ills or something to be addressed. By contrast, the film's white ufologists employ ethnic signifiers in order to crusade against what it considers the powers that be, namely the military-industrial complex, Big Oil, banks, and corporate influence in Washington (a government Greer sees as having deviated from its Jeffersonian ideals). Most conspicuous of these signifiers is the appropriation of meditation-practiced originally by yogis, Hindus, Buddhists — which Greer and his followers perform intermittently throughout the film. 
The discussion over Western engagement with a practice to native areas such as Tibet requires attention to Said's landmark research on "orientalism," the term referring to the myriad consequences of the "Western approach to the Orient." 48 The key principle is that the West maintains a "positional authority" over the Orient, bespeaking a power that privileges Greer in his adoption of meditation as a transgressive act. ${ }^{49}$ In the film, Greer leads a team of other white UFO acolytes in performing CE-5 rituals, which are intended to attract overhead alien crafts. ${ }^{50}$ The "proof" of CE-5's efficacy lies in Sirius' footage of lights sailing through the night sky above the practitioners, who typically amass in wide-open desert locales. The film suggests that the presence of the alien crafts is made possible only through an array of techniques that signify Hindu, Buddhist, and yogic spirituality — or at least Westernized imaginings of it—such as humming particular tones, moving a wooden piece around the edge of a bowl, and assuming cross-legged meditation poses. ${ }^{51}$ Oriental sartorial touches in certain scenes presumably assist in CE-5 success as well.

The white appropriation of ethnic practices to signal extraterrestrials — and by extension flout the government and corporations that have concealed alien technology-fits into an existing framework of countercultural behavior. Countercultural or subcultural movements bent on the resistance to conformity often draw on the signifiers belonging to other races. Dick Hebdige, for instance, writes of West Indian culture impacting London's punks in the 1970 s. $^{52}$ The orientalist CE-5 rituals cannot help but also harken back to the forms of 1960s countercultural behaviors that hinged on flirtation with the East, some of which were commodified under capital. Examples include the Jimi Hendrix album cover depicting the "epiphany of Krishna"53 and the Beatles experimenting with transcendental meditation under the Giggling Guru's guidance. ${ }^{54}$ 
Greer's reliance on nonwhite cultures to more effectively channel the supernatural also speaks to a crass assumption that people of color are especially attuned to magic and nature. Curtis Marez, for instance, writes that some alien abductees believe that Indians are "intimate with, or have privileged access to, extraterrestrial worlds." stating that the West expects indigenous peoples to hold a "special awareness of extraterrestrials." 56 Sirius happens to relate the testimony of a Phoenix-area doctor who, when discussing the 1997 "Phoenix lights" mass UFO sighting, asserted that the Navajo had been witnessing the aerial phenomena for centuries. The sci-fi thriller, Skinwalker Ranch (2013), similarly features white investigators on a strange property who enlist the help of a Native American man to bless it. ${ }^{57}$ The point here is that Greer's orientalist proclivity in contacting alien ships fits comfortably with the existing tension around race and ufology. But how does Greer fare in relation to capital?

\section{Capitalism and Ufology}

Early in his doctoral dissertation, Nick Dyer-Witheford discusses the meaning of subversive movements that involve actors outside of the working-class laborer (e.g., antiracists, feminists). He states that regardless of any group's idiosyncratic demands, capital views them through the lens of "opportunities for or impediments to accumulation." 58 He adds:

Because capital's a priori is profit (its own expanded replication), its logic in regard to the emancipation of women, racial justice or the preservation of the environment is purely instrumental. The prevention of male violence toward women, the saving of rain forests, or the eradication of racism is a matter of bottom line calculus: tolerated or even benignly supported 
when costless, enthusiastically promoted when profitable, but ruthlessly opposed as soon as they demand any substantial diversion of social surplus. ${ }^{59}$

Capital views ufology with the same attention to profit accumulation, which it does not view as a threat. The commodification of UFO phenomena has proven to be a boon to capital, as testified by numerous Spielbergian treatments, the long-running X-Files, and countless popular media representations. Since aliens are endlessly marketable, Sirius could not run afoul of capitalist dictates. Given Dyer-Witheford's quote, Sirius should on the contrary find itself promoted due to its drinking from the lucrative, time-tested cultural reservoir of ufology.

What of the Project's antipathy toward Big Oil and the banking establishment? Wouldn't this render it inimical to capital? As I touched on above, the answer can indeed be "no" due to past positions on the subject of banks by rightwing, common-sense populist ideology that can align with the state as it carries out the maintenance of hegemonic order. Moreover, Sirius' producers advocate bringing innovative technologies to the marketplace and instituting a paid video-on-demand distribution system for the film — as opposed to streaming it for no charge. Producer J.D. Seraphine explained in a promotional interview on Vancouver's UFOPM why this is the case. Despite expressing some grievances with the capitalist system, Seraphine claimed that offering Sirius in its totality on YouTube would have done violence to the film's legitimacy, causing it to appear amateur and uninteresting. The film's director likewise expressed vague distaste for capitalism but claimed that viewers would only engage with the film if they paid for it. ${ }^{60}$ The two had devised AffiliateConnect through the website, Yekra, which allows crowdfunders to receive some revenue by circulating the film on their personal websites. ${ }^{61}$ Relatedly, Seraphine attacked the Pirate Bay and similar file-sharing outlets for hurting independent filmmakers, whom the producer asserted are only trying to eke 
out a living by spreading the truth. But despite the earnest posturing, two commenters below the review of the interview remained unconvinced; Henrik Hellstrand wrote: "Are you here to save the world or are you here to make money? You can't have both."62 Other critics complained about the film's cost too. ${ }^{63}$

Seraphine stated that the team would allocate film revenues to the construction of a free energy lab under Greer's supervision-which according to Greer carries the price tag of $\$ 6.3$ million. ${ }^{64}$ But Seraphine's optimism on free energy devices and their potential to change the socioeconomic order is as problematic as his distribution model. This is due to his insistence that the devices be developed under the logic of profit accumulation, admitting in the interview that once the team finds a functioning free energy device, it will assemble the appropriate entrepreneurs to ensure its arrival to the marketplace. The premier science startup featured in Sirius - Morningstar Applied Physics — will no doubt function in the same way after having mastered, for instance, the exotic field of zero-point energy. According to Morningstar's website, the outfit vows to protect intellectual property rights of those proposing ideas for new devices in its quest for a new "commercially useful product." 65 Thus there is little evidence that Morningstar and its ilk harbor anticapitalist ideologies.

In a 2010 radio broadcast, Greer himself admitted to the profitable opportunities that await the architects of a new energy infrastructure, stating that "there would be a great industry in making these new energy devices and getting them to replace the old ones that are based on fossil fuels." ${ }^{66}$ According to a revealing statement in Sirius, Greer attempted to get a leg up on the competition by bidding for the estate of Stanley Meyer-a dabbler in unconventional technology. 
Yet Greer's entrepreneurial position on the lucrative possibilities of a new energy industry is tempered by some of his other statements. ${ }^{67}$ Speaking on a radio program after the film's release, he stated that the society he envisions emerging out of the coal and oil regime will be free of poverty. ${ }^{68}$ Secondly, he indicated that the aforementioned energy lab would function under "open source" dictates, which raises some technical questions, such as whether open-sourced pursuits are anathema to capital. At least one commentator has stated that "open source, from its inception, has been avowedly pro-business." ${ }^{69}$ Moreover, Greer's ambition to construct free energy devices and engines further runs into a problem The Economist has identified when discussing the difference between open-source software and open-sourced objects. It states that creating "an open-source car is rather more problematic, since information (in the form of design and specification) constitutes only a minor ingredient... [while] the costs of materials and manufacturing would remain." ${ }^{70}$ The same costs would presumably dog any devices pioneered in Greer's lab, which would put into motion an industry working under the same existing capitalist framework.

With this position on poverty taken by Greer aside, let us consider his 2010 statement regarding profitability along with Morningstar's business model and Seraphine's entrepreneurial eagerness. With market solutions inherently inequitable, it is a wonder how far any devices will go in changing socioeconomics, or if free energy will represent a superficial change between one ownership regime to another. In this way, Sirius affiliates' forays into exotic energy are revolutionary not for the underclass but for the investor class, as Greer's and Morningstar's labs would stand as two startup projects amidst a string of others in the tradition of innovative business - the same startups that strengthen the capitalist mythology surrounding the self-made man, universal access, and the level playing field. 
The celebratory prospect of the Disclosure Project and ragtag startups is reflected in the antipathy toward ExxonMobil in Sirius. Indeed, the only thing ambling into the film's crosshairs seems to be the slogging oil, coal, and gas industries - not necessarily the capitalist system itself. Given this, the Sirius team's message is wholly prefigured by Marx's famous characterization of capital: that "all that is solid melts into air," indicating that the "bourgeoisie cannot exist without constantly revolutionizing the instruments of production, and thereby the relations of production.",71

This criticism of the Sirius affiliates' ethos is not to defend Big Oil, however. Instead, I merely wish to raise concerns over the legitimacy of green capitalist solutions, which Scott Prudham has done with attention to Branson's redirection of revenues from Virgin Airlines to Virgin Fuels for climate change's sake. Green capitalism is contradictory, because its proponents argue that "innovation and profit" can fix environmental degradation — the same factors that jeopardized it to begin with. ${ }^{72}$ Importantly, if Greer, Seraphine, and Morningstar were to get their way in producing a less destructive energy infrastructure, there would seem to be no change in exploited labor or alienation.

\section{Sirius in the Post-Fordist Economy}

Just as the Sirius team takes aim at Big Oil, it also voices complaints regarding the mainstream media, alleging that news organizations comply with the military-industrial complex. Sirius' flagship website moreover states that, "No major media group or corporation wants to see this information get out." Whether or not that claim is accurate, the general criticism approximates classic or scholarly criticism in this area and should be commended. ${ }^{73}$ Yet the dialectic of Sirius' indictments is that it then presents alternative media forms (e.g., 
social media, Web 2.0) in an uncritical capacity. This occurs when the documentary features amateur YouTube videos that depict "life-hacking" contraptions that produce energy and power light bulbs by unlikely means, producing the conception that these media-popular and participatory outlets - are the only communication channels offering such emancipatory information. The establishment media, in bed with the banking and energy interests, would conversely repress these videos in order to hemorrhage the control over energy at the top.

In this sense, participatory media become articulated to the Sirius affiliate's slick forms of entrepreneurialism that back free energy devices, and the mainstream media (charged with marginalizing the film's causes) become articulated to archaic Big Oil. Again, I do not mean to dispute the fact that decisions made by media ownership conform to financial interests - in fact, that is one of Edward Herman and Noam Chomsky's media propaganda filters. ${ }^{74}$ Rather, I wish to highlight the danger in uncritically vaunting Web 2.0 and the precarious labor it has taken to sustain it. Indeed, Web 2.0 comes laden with its own drawbacks that tie into the larger exigencies of post-Fordism. I also wish to show how Seraphine, the documentary, Greer, and the Disclosure Project website all pose as promising market actors in the new capitalist paradigm.

The epoch arose out of the crumbling Fordist era (circa 1940s-1973)—marked by full and lifelong employment, factory labor, a strong welfare apparatus, and mass production met by mass consumption. Reasons for the transformation include the globalization of business, social resistance to a rigid order, and stagnating consumption of factory-made commodities. Post-Fordism also witnesses the adoption of neoliberal ideals by politicians leading to the "responsibilization" of citizens, which requires them to "absorb more of the responsibility for handling the ups and downs of a more marketized society." ${ }^{, 75}$ Citizens have no choice but to do 
so as rightwing politics cuts social safety nets at the federal level, displacing the onus of protection and representation on local governments that cannot handle the workload. ${ }^{76}$

Post-Fordism's economic trappings involve the twin concepts of "flexibility" and "precarity," the latter of which Judith Butler describes as the "fundamental condition of life."77 The concepts are manifested in the "lean workplace,",78 which expects employees to both engage in freelance work sans union representation and to sign limited contracts that involve constant reskilling. ${ }^{79}$ Workers in this paradigm also experience ceaseless instability in wages; jobs meanwhile prioritize creativity over manufacturing. Offshoring, outsourcing, insourcing, and in recent cases, reshoring, represent common attempts by employers to secure profits. Among the factors sustaining this flexible paradigm is a triumphant and celebratory discourse forwarded by the stewards benefiting most, which Tiziana Terranova describes inimitably as the "idealistic cyberdrool of the digerati." 80 One example includes Bill Gates' 1995 comment that capitalism was becoming "friction free." 81

The exploited labor characteristic of post-Fordism includes work conducted both at the call center and in front of the computer: programming, website design, software design, updating mailing lists, and "building virtual spaces." ${ }^{82}$ As Terranova writes, "free labor" both built and continues to maintain the potentialities of the Internet, with volunteers (dubbed "NetSlaves") working not simply out of economic coercion but rather out of enjoyment for the job to some degree. ${ }^{83}$

The types of neoliberal logics discussed thus far-working for less and expecting less from welfare and employers - explain the predicament Neverending Light Productions and the Disclosure Project found themselves in during development. As reported by Seraphine on UFOPM, Dr. Greer worked on the documentary for no pay, essentially volunteering, while 
compensation for the director and narrator failed to match industry standards. The producer himself, aside from contributing to the success of Sirius, also worked (most likely freelance) for major "blue chips" corporations such as Nike and Apple. ${ }^{84}$ When considering these revelations - the non-compensatory labor that created the film and Seraphine's precarious employment - it is clear how naturalized the post-Fordist practices are that saturate Sirius' production.

The day-to-day operations of the Disclosure Project website evince the shifting nature of labor as well. Upon close examination, it appears Greer's energies on the web are absorbed into the pervasive free labor paradigm of the contemporary period. In what could be an epigraph for the Project's site, Terranova writes that "the Internet is about the extraction of value out of continuous, updateable work, and it is extremely labor intensive. It is not enough to produce a good website, you need to update it continuously to maintain interest in it and fight off obsolescence." ${ }^{85}$ This is true for Greer as he puts out routine mass emails calling attention to events, such as upcoming guest appearances. At the end of 2013 at least, these messages averaged to 10 in four months - almost weekly. Similarly, the sidebar flanking the Project's website presents Greer's latest Twitter activity, indicating that post-Fordist labor in the media has no choice but to constantly build so as to stave off the anonymizing maw of the Internet.

Terranova also contends that the key to maintaining a successful website is not only to encourage users to access it but to implicate them in its constant construction. In other words, "users keep a site alive through their labor... [by] writing messages, participating in conversations, and sometimes making the jump to collaborators." $" 86$ As we have seen, Neverending Light encouraged crowdfunding Greer fans to become collaborators and 
smalltime profiteers in the film by advertising it on their personal sites. On UFOPM, Seraphine also implored listeners to "stay tuned to our Facebook," where they can receive updates and participate in conversations. Tellingly, the option to "Forward this email" appears at the bottom of each of Greer's messages, thus incorporating enthusiasts to contribute their own free labor to the preservation of the Project. A final characteristic bespeaking the Project's position within post-Fordism involves the small-scale production and distribution of immaterial goods (i.e., downloads) as opposed to material ones (i.e., DVDs). As mentioned earlier, the site accommodates for DVD purchases, but these appear as ancillary to the more flexible video-ondemand downloads. As Brophy writes, contemporary work is often geared toward the immaterial goods of "information, communication, or an emotional response." 87

What is important to take away from these realities is not just that Sirius affiliates are simply actors in a new capitalist epoch. I go a step further by criticizing their positions, though not necessarily the platforms that deliver those positions (to be sure, I only mean to say that the Sirius team's engagement with post-Fordist business practices has the consequence of illustrating their disapproval of Fordist business practices, like ExxonMobil's production). As such, I argue that all of Seraphine's and the film's lip service to anticapitalism is simply that: lip service. What the team really dislikes is an aging form of profit accumulation that they are rapidly leaving in the digital dust. They opt instead for fresh forms of market possibilities at their control in a tradition of revolutionary capitalism going back to Marx's observations. Emerging for them is the post-Fordist business model that ironically exploits their efforts at the same time it appears to them as the midwife to socioeconomic justice.

Lastly, I would comment that their abiding by post-Fordist exigencies does not necessarily jeopardize their integrity. It would be difficult after all to work outside of any 
dominant economic context. However, their determination to voluntarily superimpose market logic on the distribution of Sirius and the introduction of free energy machines does raise eyebrows. Would not the inventors of an egalitarian technology reject the intellectual property pretense? Morningstar and Greer do not think so.

\section{Conclusion: Legacy of UFO Culture}

I chose to examine the raced and classed consequences of the UFO culture's actions and the way these have been mediated through Sirius. I argue that ufology represents a rich site of signification, but not exactly a site of struggle against dominant forces. In fact, it too often sides with strong power-and especially slick, post-Fordist and green capitalist entrepreneurialism - to pose as a viable challenge to the status quo. The same goes for ufology's rampant insensitivity to racial difference. Whereas ufology's proponents may indeed engage in counterhegemonic battles with established forces, any resistant sentiments become foreclosed by capital, never shake the exploitative economic system to its core, or never see capitalism as anything but a natural phenomenon. This was the case with the tangle of exploits, hopes, and fears surrounding Sirius' affiliates. If Greer and Seraphine wanted to improve American socioeconomics as they claim, they should compose a witness list on the way to

Congress not of high-level ET believers, but of Marxists ready to "disclose" the merits of commonly held property. 


\section{REFERENCES}

Enda Brophy, "System Error: Labour Precarity and Collective Organizing at Microsoft," Canadian Journal of Communication 31 (2006).

Jodi Dean, "The Truth is Out There: Aliens and the Fugitivity of Postmodern Truth," Camera Obscura 40-41 (1997).

John Fiske, Power Plays, Power Works (New York \& London: Verso, 1993).

Stuart Hall, "Race, Articulation, and Societies Structured in Dominance," in Black British Cultural Studies: A Reader, eds. Houston A. Baker, Manthia Diawara, and Ruth H. Lindeborg (Chicago \& London: University of Chicago Press, 1996).

Hebdige, Subculture (London \& New York: Methuen, 1983).

Hermann and Noam Chomsky, Manufacturing Consent (New York: Pantheon, 2002).

Richard Sennett, The Culture of the New Capitalism (New Haven \& London: Yale University Press, 2006).

\section{ENDNOTES}

${ }^{1}$ Emmanuel Renault, "From Fordism to Post-Fordism: Beyond or Back to Alienation?" trans. Steven Corcoran, Critical Horizons 8 (2007): 205-220.

${ }^{2}$ The claim is made on the film's page, http://www.siriusdisclosure.com/sirius-film-2/.

${ }^{3}$ Jim Marrs, Alien Agenda (New York: HarperCollins, 1997). Modern form, 79. "Flying saucer,” 81.

${ }^{4}$ John A. Saliba, “The Study of UFO Religions,” Nova Religio 10 (2006): 103-123.

${ }^{5}$ Anne Cross, “The Flexibility of Scientific Rhetoric: A Case Study of UFO Researchers,” Qualitative Sociology 27 (2004): 3 34.

${ }^{6}$ Jodi Dean, "The Truth is Out There: Aliens and the Fugitivity of Postmodern Truth," Camera Obscura 40-41 (1997), 42.

${ }^{7}$ Steven M. Greer, “Project Background,” accessed May 23, 2014, http://www.disclosureproject.org/background.shtml.

${ }^{8}$ Ibid.

${ }^{9}$ Ibid.

${ }^{10}$ Jon Kelly, “Sirius producer J.D. Seraphine LIVE on UFOPM,” YouTube video, http://www.youtube.com/watch?v=NJxH5hisEJY\&feature=youtu.be.

${ }^{11}$ Sirius Documentary, "Sirius documentary - Sirius the movie - Sirius 2013 - Sirius release - Film Sirius - Sirius,” YouTube video,

http://www.youtube.com/watch?v=4ORHQsnpmgU.

${ }^{12}$ Patricia Felisa Barbeito, “'He’s Making Me Feel Things in My Body That I Don’t Feel’; The Body as Battleground in Accounts of Alien Abduction," Journal of American Culture 28 (2005), 205.

${ }^{13}$ Whitley Strieber, Communion (New York: Avon, 1987), 57.

${ }^{14}$ Robert Sheaffer, “Greer's 'Sirius' documentary - no ‘bombshell,' just nonstop UFO claims,” accessed May 23, 2014, 
http://badufos.blogspot.ca/2013/04/greers-sirius-documentary-no-bombshell.html.

${ }^{15}$ Stuart Hall et al., Policing the Crisis (Hampshire, UK: Palgrave Macmillan, 2013), 328.

${ }^{16}$ Ibid., xii.

${ }^{17}$ Richard Sennett, The Culture of the New Capitalism (New Haven \& London: Yale University Press, 2006).

${ }^{18}$ Enda Brophy, "System Error: Labour Precarity and Collective Organizing at Microsoft," Canadian Journal of Communication 31 (2006), 622.

${ }^{19}$ Scott Prudham, "Pimping Climate Change: Richard Branson, Global Warming, and the Performance of Green Capitalism," Environment and Planning 41 (2009), 1596.

${ }^{20}$ Ibid., 1595.

${ }^{21}$ Ibid., 1596.

${ }^{22}$ John Fiske, Power Plays, Power Works (New York \& London: Verso, 1993), 12.

${ }^{23}$ Stuart Hall, "Race, Articulation, and Societies Structured in Dominance," in Black British Cultural Studies: A Reader, eds. Houston A. Baker, Manthia Diawara, and Ruth H. Lindeborg (Chicago \& London: University of Chicago Press, 1996$), 45$.

${ }^{24}$ Fiske, Power Plays, Power Works, 120.

${ }^{25}$ Ibid., 188.

${ }^{26}$ Cross, "The Flexibility of Scientific Rhetoric," 8.

${ }^{27}$ Ibid., 14.

${ }^{28}$ Dean, "The Truth is Out There," 49.

${ }^{29}$ Dorceta E. Taylor, “The Rise of the Environmental Justice Paradigm,” American Behavioral Scientist 43 (2000), 510.

${ }^{30}$ Ibid., 510.

${ }^{31}$ Ibid., 516.

32“"Dr. Steven Greer and Dr. Ted Loder on Free Energy Technology,” accessed May 23, 2014,

http://goldenageofgaia.com/disclosure/how-will-the-galactics-help-us/dr-steven-greer-and-dr-ted-loder-on-free-energy-

technology/.

${ }^{33}$ Taylor, "The Rise of the Environmental Justice Paradigm," 513.

${ }^{34}$ Jan Harzan, a MUFON director and student of nuclear engineering, reveals this in Sirius.

${ }^{35}$ Strieber, Communion, 216.

${ }^{36}$ bell hooks, Killing Rage (New York: Holt, 1995), 39.

${ }^{37}$ Ibid., 39.

${ }^{38}$ Elspeth Kydd, "Differences: The X-Files, Race and the White Norm,” Journal of Film and Video 53 (2001-2002), 78.

${ }^{39}$ Heather J. Hicks, “Suits vs. Skins: Immigration and Race in Men in Black," Arizona Quarterly 63 (2007), 112.

${ }^{40}$ Kydd, "Differences," 74.

${ }^{41}$ Jason Colavito, “Ancient Astronauts and Racism,” accessed May 23, 2014, http://www.jasoncolavito.com/1/post/2012/07/ancient-astronauts-and-racism.html.

${ }^{42}$ Barbeito, “'He’s Making Me Feel Things in My Body I Don’t Feel,’” 201. 
${ }^{43}$ David Drysdale, “Alienating Histories, Alienating Futures: Raciology and Missing Time in The Interrupted Journey," English Studies in Canada 34 (2008), 116.

${ }^{44}$ J. Griffith Rollefson, “The 'Robot Voodoo Power' Thesis: Afrofuturism and anti-anti-essentialism from Sun Ra to Kool Keith,” Black Music Research Journal 28 (2008), 84.

${ }^{45}$ Stephen C. Finley, “The Meaning of Mother in Louis Farrakhan's 'Mother Wheel': Race, Gender, and Sexuality in the Cosmology of the Nation of Islam's UFO.” Journal of the American Academy 80 (2012), 450.

${ }^{46}$ Ibid., 440.

${ }^{47}$ Eirik Saethre, “UFOs, Otherness, and Belonging: Identity in Remote Aboriginal Australia,” Social Identities 13 (2007), 223.

${ }^{48}$ Edward Said, Orientalism (New York: Vintage, 1978), 7.

${ }^{49}$ Ibid., 7.

${ }^{50}$ It bears mentioning that Sirius director, Amardeep Kaleka—an Indian-American Buddhist-did have experience with meditation before approaching the project.

${ }^{51}$ While meditative techniques are not exclusive to Hinduism or Buddhism, meditation's origins are clearly not located in the West. Kavita Maharaj writes that the history begins in the Indus Valley, and that the techniques include "prayer, meditating on the scriptures, mantra meditation, chanting meditation, [and] singing songs of praise" in "A Brief History of Meditation," Nanaimo News Bulletin 31 (2007), 31.

${ }^{52}$ Dick Hebdige, Subculture (London \& New York: Methuen, 1983).

${ }^{53}$ David Edleson, “Thank you, India II: Hippies, Hindus, and the Counter-Culture,” accessed May 23, 2014,

http://professoredleson.blogspot.ca/2013/02/hippies-hindus-and-counter-culture.html.

${ }^{54}$ Lily Koppel, “Maharishi Mahesh Yogi, Spiritual Leader, dies,” New York Times (2008), accessed May 23, 2014, http://www.nytimes.com/2008/02/06/world/asia/06maharishi-1.html? r=2\&oref=slogin\&.

${ }^{55}$ Curtis Marez, “Aliens and Indians: Science Fiction, Prophetic Photography and Near-Future Visions,” Journal of Visual Culture 3 (2004), 344.

${ }^{56}$ Saethre, "UFOs, Otherness, and Belonging," 218.

${ }^{57}$ Various tribes did host a 1996 Star Knowledge Conference with the intention of sharing with non-indigenous peoples their experiences with UFOs, indicating that some Native Americans do express insight on the subject.

${ }^{58}$ Nick Dyer-Witheford, Cyber-Marx: Cycles and Circuits of Struggle in High-Technology Capitalism, accessed May 23, 2014, http://libcom.org/library/cyber-marx-nick-dyer-witheford.

${ }^{59}$ Ibid., 16.

${ }^{60}$ Jon Kelly, “Sirius director Amardeep Kaleka LIVE on UFOPM,” YouTube video, http://www.youtube.com/watch?v=J1Iif YmZY.

${ }^{61}$ Kelly, "Sirius producer J.D. Seraphine LIVE on UFOPM."

${ }^{62}$ Kelly, "Sirius producer wants profits for crowdfunders, truth for the masses," accessed May 23, 2014, 
http://www.examiner.com/article/sirius-producer-wants-profits-for-crowdfunders-truth-for-the-masses. Two other commenters approved of the distribution system, however.

${ }^{63}$ Whitley Strieber, “The Disappointing, Tantalizing Case of the Sirius Documentary,” accessed May 23, 2014,

http://www.unknowncountry.com/journal/sirius-documentary. Robert Sheaffer, cited above, also complained.

${ }^{64}$ Revolutionize TV, “Steven Greer - Sirius Film, Free Energy, ET’s and Freeing Humanity from the NWO,” YouTube video, http://www.youtube.com/watch?v=urvSE7pimqI.

${ }^{65}$ Morningstar Applied Physics, "Proposals,” accessed May 23, 2014,

http://www.morningstarap.com/proposals.html.

66، Dr. Steven Greer and Dr. Ted Loder on Free Energy Technology."

${ }^{67}$ Denise M. Wilbanks, “The Intent Beneath the Sirius Documentary part 2,” accessed May 23, 2014,

http://www.huffingtonpost.com/denise-m-wilbanks/the-intent-beneath-the-si 1 b 3252659.html.

The author offers a different take on the future Greer foresees, stating that Sirius is part of the class struggle.

${ }^{68}$ Revolutionize TV, “Steven Greer - Sirius Film, Free Energy, ET’s and Freeing Humanity from the NWO.”

${ }^{69}$ Matt Asay, “Sorry Socialists: Open Source is a Capitalist's Game,” accessed May 23, 2014,

http://news.cnet.com/8301-13505 3-10170649-16.html.

70،"Beyond Capitalism?” The Economist, accessed May 23, 2014,

http://www.economist.com/node/2747734.

${ }^{71}$ Karl Marx and Friedrich Engels, "The Communist Manifesto" in Karl

Marx: Selected Writings, ed. Lawrence H. Simon (Indianapolis: Hackett, 1994), 161-162.

${ }^{72}$ Prudham, "Pimping Climate Change," 1595.

${ }^{73}$ Such scholars include Ben Bagdikian (The Media Monopoly), Edward Herman and Noam Chomsky (Manufacturing Consent), and Michael Parenti (Inventing Reality).

${ }^{74}$ Herman and Chomsky, Manufacturing Consent (New York: Pantheon, 2002).

${ }^{75}$ Sanford F. Schram, “Occupy Precarity,” Theory \& Event 16 (2013).

${ }^{76}$ James McCarthy and Scott Prudham, “Neoliberal Nature and the Nature of Neoliberalism,” Geoforum 35 (2004): $275-283$.

${ }^{77}$ Schram, "Occupy Precarity."

${ }^{78}$ Renault, "From Fordism to Post-Fordism," 209.

${ }^{79}$ Stated in the following:

Tiziana Terranova, "Free Labor: Producing Culture for the Digital Economy," Social Text 18 (2000): 33-58. And:

Anonymous, “Precarious Labor and Worker Struggles Against Capital's Offensive,” Working USA 13 (2010): 181-184.

${ }^{80}$ Terranova, "Free Labor," 44.

${ }^{81}$ Brophy, "System Error," 620.

${ }^{82}$ Terranova, "Free Labor," 33.

${ }^{83}$ Ibid., 36-37.

${ }^{84}$ Kelly, "Sirius Producer Wants Profits for Crowdfunders, Truth for the Masses." 
${ }^{85}$ Terranova, "Free Labor," 48.

${ }^{86}$ Ibid., 48.

${ }^{87}$ Brophy, "System Error," 621. 